\title{
ДОЦІЛЬНІСТЬ СКЛАДОВИХ МОДЕЛІ СОЦІАЛЬНОЇ АДАПТОВАНОСТІ СТАРШИХ ДОШКІЛЬНИКІВ 3 ОСОБЛИВИМИ ПОТРЕБАМИ
}

У статті розкрито особливості сочіальної адаптованості дітей старшого дошкільного віку 3 порушенням зору, слуху, мовлення. Висвітлено основні складові створеної моделі сочіальної адаптованості стариих дошкільників з особливими потребами. Проведено факторизачію ї̈ складових та доведено доцільність створення моделі соціальної адаптованості старших дошкільників з особливими потребами.

Ключові слова: сочіальна адаптованість, факторний аналіз, складові соціальної адаптованості, стариі доикільники з особливими потребами, модель соичіальної адаптованості.

Постановка проблеми. У зв'язку зі зростанням в останні десятиліття кількості дітей 3 проблемами у розвитку особливої значущості набуває їх соціальна адаптованість у суспільстві. Виходячи зі специфіки розвитку дітей даної категорії в соціальній психології склалася традиція комплексного їх вивчення для створення умов для успішної адаптації в суспільстві.

Зазначимо, що соціальна адаптація дітей дошкільного віку - це активний процес засвоєння дитиною соціального досвіду в процесі діяльності і спілкування. Тому своєчасне задоволення потреби в спілкуванні дозволить прискорити адаптаційні процеси. На ефективність соціальної адаптації впливає і спілкування дитини з вихователем, однолітками та батьками [1].

Основні закономірності психічного розвитку дітей з різними порушеннями зору, слуху та мовлення (якщо немає органічних уражень мозку) такі ж, що і у дитини без порушень. У дошкільників з особливими потребами спостерігаються ті ж вікові етапи та етапи психічного розвитку. Але в той же час в адаптації дітей з порушеннями зору, слуху та мовлення спостерігаються деякі особливості, у зв'язку з якими методи і техніка соціального і психологічного впливу інші. Вони спрямовані, насамперед, на усунення перешкод, викликаних сенсорним або мовленнєвим порушенням, які перешкоджають соціальній адаптації в навколишньому соціумі. Саме тому створення моделі соціальної адаптованості старших дошкільників 3 особливими потребами для полегшення іiі формування $\epsilon$ нагальною необхідністю.

Аналіз останніх досліджень та публікацій. Системно-структурний та комплексний підхід до вивчення адаптації дошкільників 3 порушенням зору, слуху та мовлення припускає комплексну оцінку адаптованості з урахуванням складної взаємодії біологічних, соціальних і аномальних чинників на всіх рівнях функціональної організації дитини: психофізіологічному, психологічному, особистісному, соціально-психологічному, соціальному. Очевидно, що тільки при наявності високих оцінок за зовнішнім і внутрішнім критерієм на всіх рівнях можна говорити про оптимальний варіант адаптації та комплексної адаптації [3].

Адаптованість дошкільників 3 обмеженими можливостями розвитку в соціокультурному просторі нерозривно пов'язана з залученням дитини до найважливіших сфер людської діяльності і культури праці, знань, моралі, мистецтва [4].

У дошкільний період дитина $з$ особливими потребами набуває свій соціальний досвід, успішність якого залежить від перебування іiї в дошкільному навчальному закладі. У психологічній практиці важливе значення має врахування особливостей адаптованості дитини з сенсорними та мовленнєвими порушеннями до нових умов життя і діяльності при вступі в громадські навчально-виховні заклади, при входженні у новий колектив [2].

У дітей з проблемами в розвитку мовлення (це ж стосується і проблем із зоровим та слуховим сприйняттям), через дефекти розвитку утруднена взаємодія з соціальним середовишем. знижена здатність адекватного реагування на зміни, що відбуваються, (С) Черних Л., 2019 
ускладнюються вимоги. Діти відчувають значні труднощі у досягненні своїх цілей в рамках існуючих норм, правил, що може викликати неадекватну реакцію і призвести до відхилень у поведінці [5, с. 4].

Соціальна адаптованість дітей дошкільного віку з особливими потребами залежить від багатьох чинників, основні з яких - психічне та фізичне здоров'я. Сутність соціальної адаптованості цих дітей зводиться до формування особистісних якостей (цінностей, моральності, високого рівня культури, соціально значущих рис характеру, культури спілкування, засвоєння стереотипів поведінки, діючих соціальних норм, звичаїв, інтересів, високого рівня розвитку комунікативної, емоційно-вольової, мотиваційно-потребової сфери), адекватних ситуації поведінкових проявів у грі, трудовій діяльності, навчанні; грамотного медичного та психолого-педагогічного супроводу дитини; розвитку компенсаторних можливостей, пов'язаних 3 порушенням зору; запобігання психотравмуючих ситуацій тощо. Тому потрібно створити таку модель соціальної адаптованості старших дошкільників з особливими потребами, на яку можна спиратися як на еталонну у формуванні цього важливого феномену.

Постановка завдання - довести доцільність створеної моделі соціальної адаптованості старших дошкільників з особливими потребами.

Виклад основного матеріалу дослідження. Створюючи модель соціальної адаптованості старших дошкільників з особливими потребами, ми виходимо з функціонування організму дитини як біологічної істоти, розглядаючи ії як гомеостатичну підсистему, і як соціальної особистості, з урахуванням соціальних зв'язків, особистісних особливостей, соціально-психологічних утворень - як гетеростатичну підсистему. У створенні моделі соціальної адаптованості використовувався макро- і мікропідхід, а також взаємозв'язок внутрішніх та зовнішніх чинників, які забезпечують стійкість функціонування соціальної адаптованості і особистості загалом в рамках системного підходу.

Реалізація системного підходу до вивчення соціальної адаптованості старших дошкільників з особливими потребами передбачає виокремлення соціально-психологічних умов формування соціальної адаптованості, наслідків дії механізмів соціальної адаптації, критеріїв адаптованості та чинників, які впливають на соціальну адаптованість. Вони складають спрощену структурно-функціональну модель соціальної адаптованості старших дошкільників з особливими потребами.

Внутрішню організацію механізмів соціально-психологічної адаптації складає процес, який пов'язаний із соціалізацією дитини в новому для неї середовищі і проходить три фази, що відзначаються через діяльність, спілкування, самосвідомість і впливають на соціально-психологічну адаптованість до стресу та психологічну готовність до школи. Внутрішню організацію критеріїв соціальної адаптованості складають два параметра: внутрішні та зовнішні критерії, або об'єктивні і суб'єктивні. Внутрішню організацію чинників, які впливають на соціальну адаптованість дошкільника з особливими потребами, імітують такі структурні елементи: психофізіологічний, психологічний, соціальнопсихологічний, соціальний та особистісний чинники. Окремим елементом виступають соціально-психологічні умови формування соціальної адаптованості старших дошкільників 3 сенсорними та мовленнєвими порушеннями. Відповідно, структурні складові соціальнопсихологічних умов формування соціальної адаптованості, наслідків дії механізмів соціальної адаптації, критеріїв адаптованості та чинників, які впливають на соціальну адаптованість імітують внутрішню організацію об'єкта-прототипу - структурнофункціональну модель соціальної адаптованості старших дошкільників 3 особливими потребами (рис. 1). 


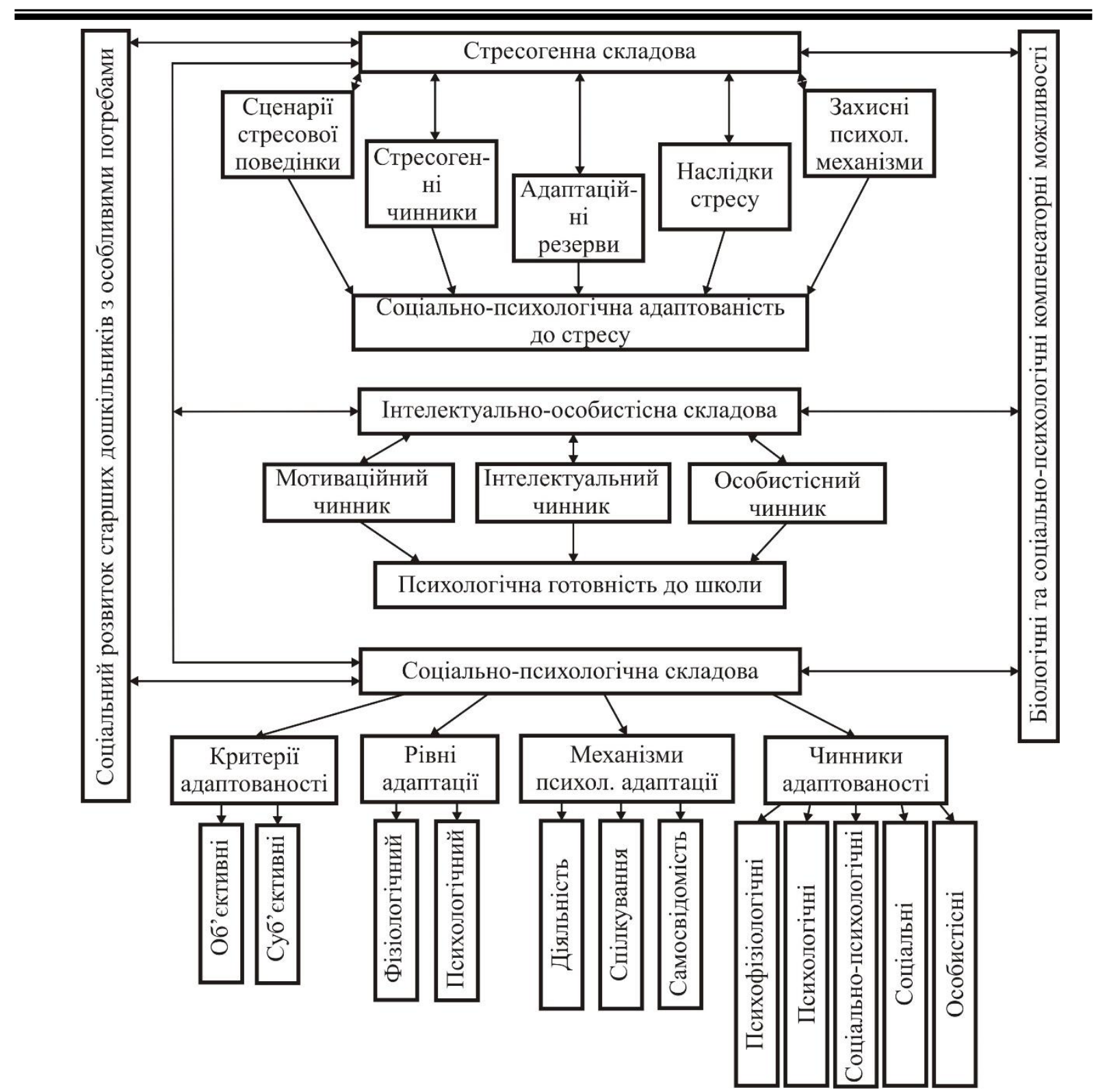

Рuc. 1. Структурно-функціональна модель соціальної адаптованості старших дошкільників з особливими потребами.

У запропонованій моделі сутність соціальної адаптованості старших дошкільників 3 особливими потребами визначається рівнем соціального розвитку таких дітей i детермінується біологічними і соціально-психологічними компенсаторними можливостями, пов'язаними з порушеннями зору, слуху та мовлення. Соціальна адаптованість згідно 3 моделлю - це визначення рівноваги між дитиною з особливими потребами і середовищем. Причому, дитина в цьому процесі - не тільки активний перетворювач свого мікросоціуму 3 його системою цінностей, моральності, культури, особливостями спілкування, особистісними особливостями, змінами мотиваційної, вольової, емоційної, інтелектуальної сфер, а й суб'єкт впливу на соціальне оточення, соціум у більш широ кому його розуміння, а також об'єкт виховання з боку сім'ї, значущих дорослих, соціальних інститутів.

Соціальний розвиток дитини дошкільного віку з особливими потребами - це багатокомпонентний конструкт, який включає культуру пізнання дорослих і дітей; соціальні емоції і мотиви налагодження міжособистісних відносин; етично цінні способи спілкування; повагу до себе й оточуючих; сформовані цінності, моральність, здатність до емпатії; відповідальність за свої вчинки; рівень розвитку мовлення й мовленнєвого спілкування тощо, що зумовлює його розгляд з системних позицій. 
Композиція розміщення структурних складових наступна: 1) стресогенна складова: загальний адаптаційний синдром (стрес-реакція) - порушення зору, слуху, мовлення, за допомогою стресогенних чинників активує адаптаційні резерви та захисні психологічні механізми, задіюючи сценарії стресової поведінки, враховуючи наслідки стресу, який спонукає дитину до формування соціально-психологічної адаптованості до стресу; 2) інтелектуально-особистісна складова, яка включає мотиваційний, інтелектуальний та особистісний чинники, що зумовлює формування психологічної готовності до школи, що є цілком очікуваним у старшому дошкільному віці; 3) соціально-психологічна складова, яка включає механізми соціально-психологічної адаптації до стрес-реакції, які діють, як i механізми соціалізації, через діяльність, спілкування, самосвідомість, формуючи соціальну адаптованість старших дошкільників з особливими потребами; об'єктивні і суб'єктивні критерії наявності або відсутності соціальної адаптованості; чинники, які впливають на соціальну адаптованість дітей старшого дошкільного віку з порушенням функціонування сенсорів і мовленнєвими порушеннями. Модель соціальної адаптованості старших дошкільників з особливими потребами буде функціонувати лише за певних соціальнопсихологічних умов, завдяки яким соціальна адаптованість старших дошкільників 3 особливими потребами буде сформована.

Серед умов найбільш значущими є сенситивність дошкільного віку для засвоєння суспільних норм, формування адаптивної поведінки, розвиток адаптаційних механізмів, включення дитини в різноманітні змістовні види діяльності, ефективна співпраця дошкільного навчального закладу з родиною, наявність і ціннісно-смислове навантаження об'єкта адаптації, бажання діяти, бажання боротися за покращення здоров'я або компенсацію цього становища певними видами зайнятості, достатнє спілкування зі спеціалістами-вчителями, якщо навчання організоване на дому, достатнє спілкування 3 ровесниками, участь у корисних суспільних справах, у груповій роботі, оприлюднення результатів індивідуальної роботи таких дітей, щоб вони повірили у свою повноцінність як особистості і як члена соціуму. Соціальна адаптованість старшого дошкільника 3 особливими потребами репрезентує соціально-психологічну реальність, наявність предмету соціальної адаптованості, перехід від об’єкта до предмета соціальної адаптованості, довільну регуляцію соціальної адаптованості старшого дошкільника 3 порушеннями зору, слуху, мовлення, наявність складових процесу адаптації і адаптованості як його результату, наявність когнітивної, емоційної, поведінкової готовності до дії, джерелом і носієм соціальної адаптованості $€$ особистість дитини дошкільного віку 3 особливими потребами.

Структурні складові соціальної адаптованості старших дошкільників з особливими потребами та їх змістові структурні елементи розглянуті нами у нерозривній єдності, рівень розвитку, рівень сформованості та рівень здатності яких можна оцінювати як показники міри сформованості окремих підсистем та соціально-психологічного феномену загалом.

Варто зазначити, що поділ виокремлених складових соціальної адаптованості старших дошкільників з порушенням зору, слуху, мовлення на структурні елементи дещо умовний, оскільки один структурний елемент може входити до кількох складових, зокрема структурний елемент “соціально-психологічна адаптованість до стресу”, який ми віднесли до складової механізмів соціальної адаптованості, також має відношення до інших складових моделі, але з меншою мірою зв'язку.

Спираючись на виділені структурні елементи моделі, можна визначити, що соціальна адаптованість старших дошкільників з особливими потребами - це властивість особистості, придбана внаслідок реакції на психофізіологічні та соціально-психологічні стресогенні події, яка допомагає засвоєнню соціокультурного простору, складові якої закладені в модель.

3 метою дослідження структури показників дослідження використовувався факторний аналіз методом головних компонент. Ми не мали на меті досягнення найвищої якості факторної структури, натомість прагнули виявити групи показників, які можна 
інтерпретувати. Ми не мали гіпотези про незалежність факторів, тому використали метод обертання факторної матриці “облімін”, який дозволяє виділяти потенційно залежні фактори, втім, вони залишаться незалежними, якщо автоматичний алгоритм визначить, що це $\epsilon$ їх оптимальна конфігурація.

Для визначення кількості факторів використовувався метод параллельної факторизації. Для методу головних компонент, лінія зменшення власних значень, розрахована на симульованих даних, перетинає лінію, розраховану на реальних даних, на рівні 15 факторів. Тож, слід виділяти 15 чи менше головних компонент (рис. 2).

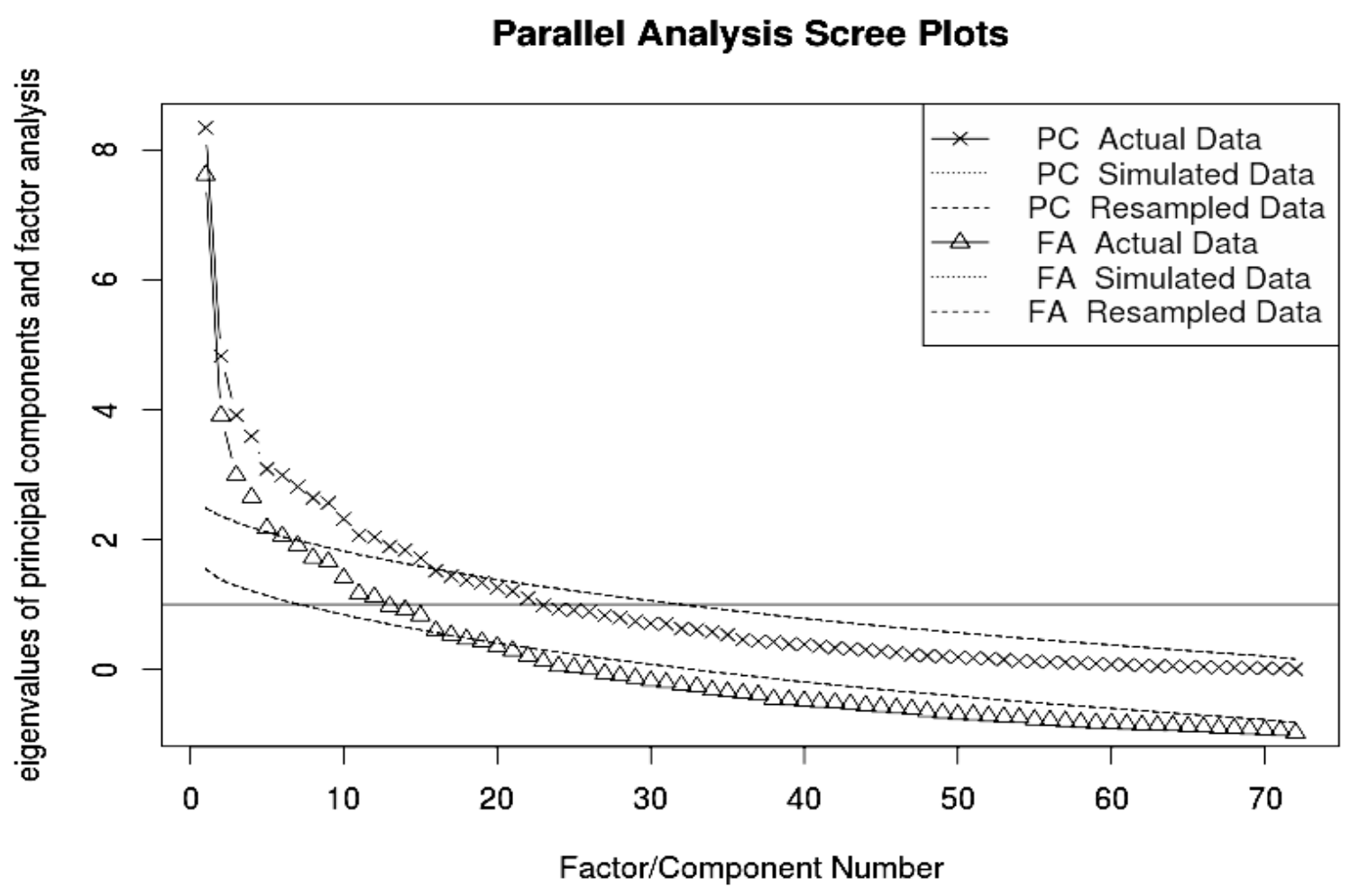

Рис. 2. Визначення кількості факторів за допомогою методу параллельної факторизації

Перша спроба виділити 15 головних компонент показала, що 5 останніх з них не містять змінних з навантаженнями більше 0,5 , тож, остаточним варіантом стала кількість у 10 головних компонент.

Розглянемо матрицю навантажень. Сумарна частка поясненої дисперсії складає 51\%, що $є$ низьким значенням з позиції якості аналізу, але отримана матриця навантажень у достатній мірі розкриває структуру змінних, щоб перейти до їі аналітичного опису.

До фактору 1 увійшли показники 3 факторними навантаженнями більше 0,5: ставлення до матері $(-0,53)$; ставлення до друга $(0,75)$; ставлення до вчителя $(0,69)$. Основний зміст цього фактора складає позитивне ставлення до друга та вчителя, при цьому можливе негативне ставлення до матері. Проте навантаження показника негативного ставлення до матері невелике, тому ми не можемо говорити про цей показник як про змістоутворюючий для даного фактора. Показники цього фактору є соціально-психологічними чинниками адаптованості, які входять до складу соціально-психологічної складової соціальної адаптованості старших дошкільників з особливими потребами.

До фактору 2 увійшли показники: позитивне ставлення до дошкільника $(0,67)$; позитивне ставлення до школяра $(-0,67)$, цей показник вказує на неготовність до шкільного навчання, негативне ставлення до позиції школяра; потреби (згадування покарання за провину) (0,54). Показники цього фактору входять до складу мотиваційного та особистісного чинників інтелектуально-особистісної складової соціальної адаптованості старших дошкільників з порушенням зору, слуху, мовлення. 
До фактору 3 увійшли показники: страхи (втрата любові, схвалення) $(0,85)$; страхи (самота, відсутність підтримки) $(0,85)$; сприйняття навколишнього середовища дружнє ($0,75)$. Основний зміст цього фактора складають страхи, тому можливе негативне ставлення до дружнього навколишнього середовища. Показники цього фактору входять до чинника наслідки стресу, який входить до складу стресогенної складової соціальної адаптованості старших дошкільників з сенсорними та мовленнєвими порушеннями.

До фактору 4 увійшли показники: головні потреби (активно-агресивна розповідь) ($0,67)$; Я-образ (адекватні уявлення про себе) $(0,6)$; головний герой (адекватність поведінки) $(0,6)$; товариськість $(0,5)$. Активно-агресивна розповідь меншою мірою властива дітям 3 адекватною поведінкою і уявленнями про себе, доброзичливим дітям. Показники цього фактору входять до особистісних, соціальних, психологічних чинників адаптованості, а також до механізмів соціальної адаптації у складі соціально-психологічної складової моделі соціальної адаптованості старших дошкільників з особливими потребами.

До фактору 5 увійшли показники: догана $(0,71)$, ігнорування $(0,69)$, ізоляція $(0,6)$, прибирання іграшок $(0,58)$, інтропунітивна реакція 3 фіксацією на перешкоді $(-0,52)$. Інтропунітивна реакція з фіксацією на перешкоді меншою мірою властива дітям 3 ігноруванням, ізоляцією, доганою. Показники цього фактору належать до стресогенних чинників та адаптаційних резервів, які входять до складу стресогенної складової соціальної адаптованості старших дошкільників з сенсорними та мовленнєвими порушеннями.

До фактору 6 увійшли показники: ставлення до батьків як до родини $(0,81)$, ставлення до батька $(0,78)$, ставлення до братів та сестер $(-0,72)$, цей показник свідчить про можливу наявність конкуренції між сіблінгами за увагу батьків, допитливість $(-0,56)$. При наявності позитивного ставлення до батьків як до родини та до батька як значущого дорослого, які задовольняють цікавість дитини з порушеннями сенсорної та мовленнєвої сфери, показник допитливість втрачає свою провідну роль. Показники цього фактору входять до рівнів адаптації, а також до особистих, психологічних чинників адаптованості, які є складниками соціально-психологічної складової соціальної адаптованості старших дошкільників з особливими потребами.

До фактору 7 увійшли показники: дитя й мати з немовлям $(0,69)$, гра 3 молодшими дітьми $(0,65)$, одягання $(0,61)$, умивання $(0,54)$. Показники цього фактору належать до механізмів психологічної адаптації, що входять до складу соціально-психологічної складової соціальної адаптованості старших дошкільників з порушенням зору, слуху, мовлення.

До фактору 8 увійшли показники: тема (дитина покинута) (0,65), тема (мало уваги від мами) (-0,6); тема (страх) (-0,55); страхи (можливе покарання) $(0,51)$, потреби (згадування їжі) $(0,5)$. Показники дитина покинута, страх можливого покарання, згадування їжі як потреба у материнській любові зумовлюють показники мало уваги від мами й тему страхів. Показники цього фактору включають сценарії стресової поведінки, стресогенні чинники, адаптаційні резерви, захисні психологічні механізми, які $є$ складниками стресогенної складової соціальної адаптованості старших дошкільників 3 особливими потребами.

До фактору 9 увійшли показники: схильна до діяльності гуляти $(-0,58)$; потреби матеріальні $(0,55)$, сприйняття навколишнього середовища вороже, небезпечне $(0,54)$. Діти, які сприймають навколишнє середовище як вороже, у яких превалюють матеріальні потреби, не завжди матимуть бажання гуляти. Показники цього фактору є складниками критеріїв адаптованості та механізмів психологічної адаптації, які входять до соціальнопсихологічної складової соціальної адаптованості старших дошкільників з особливими потребами.

До фактору 10 увійшли показники: соціальна адекватність поведінки $(-0,75)$; закритість, відокремленість $(-0,68)$; інтропунітивна реакція з фіксацією на самозахисті $(0,67)$, ставлення до прабатьків $(0,6)$, ставлення до матері $(0,59)$, здібність до навчання в школі $(0,58)$, усвідомлення власних можливостей $(0,53)$. Показники ставлення до матері, до 
прабатьків, усвідомлення власних можливостей, здібність до навчання в школі зумовлюють відкритість для соціальних контактів замість закритості, відокремленості, при цьому інтропунітивна реакція 3 фіксацією на самозахисті нівелює соціальну адекватність поведінки дитини з особливими потребами. Показники даного фактору входять до складу інтелектуального та особистісного чинників інтелектуально-особистісної складової, а також до соціального, особистісного чинників адаптованості та механізмів психологічної адаптації соціально-психологічної складової моделі соціальної адаптованості старших дошкільників з особливими потребами.

Висновки 3 проведеного дослідження. Таким чином, складники кожного фактору входять до складових моделі соціальної адаптованості старших дошкільників з особливими потребами. Зокрема, до стресогенної складової належать фактори 3, 5, 8; до інтелектуальноособистісної складової належать фактори 2, 10; до соціально-психологічної складової входять фактори $1,4,6,7,9,10$. Отже, було емпірично підтверджено доцільність виділення стресогенної, інтелектуально-особистісної та соціально-психологічної складових структурно-функціональної моделі соціальної адаптованості старших дошкільників 3 особливими потребами.

1. Ватутина Н. Д. Педагогические условия адаптации детей 3 года жизни к системе общественного воспитания : автореф. дис. ... канд. пед. наук. Москва, 1979. 19 с.

2. Доронова Т. Н., Гербова Г. Г., Гризик Т. И., Соловьева Е. В., Якобсон. С. Г. Радуга. Москва, 1996. 189 с.

3. Луцко Е. А. К вопросу об определении критериев и факторов эффективности адаптации. Вестник СанктПетербургского ун-та. Серия 12. Вып. 1. 2008. С. 205-209.

4. Плаксина Л. И. Социальная адаптация ребенка с нарушением зрения в условиях сенсорного воспитания : [дошкол. возраст]. Проблемы воспитания и соииальной адаптации детей с нарушением зрения. Москва, 1995. C. 5-28.

5. Соботович Е. Ф. Психолингвистическая структура речевой деятельности и механизмы ее формирования. Київ : ІЗМН, 1997. 44 c. 